\title{
The effect of phosphours and water deficit on phosphatase activity and proline accumulation in seedling cotyledons and roots of oilseed rape as compared to that of excised cotyledons and roots
}

\author{
STANISŁAW FLASIŃSKI, JANINA ROGOZIŃSKA, LUCYNA DROZDOWSKA
}

Department of Plant Physiology, Faculty of Agriculture, Technical-Agricultural University, Bernardyńska 6, 85-029 Bydgoszcz, Poland

(Received: August 6, 1985. Accepted: August 31, 1985)

\begin{abstract}
Oilseed rape seedlings and excised cotyledons and roots were exposed to phosphorus and osmotic stress $(-1 \mathrm{MPa}: \mathrm{NaCl}$ or PEG). The stress factors limited the growth of the seedlings and inhibited the growth of the excised roots and cotyledons. The phosphorus content in the cotyledons and roots depended on its level in the media and on the stress factors used. Phosphorus deficiency differentiated total phosphatase activity in seedling cotyledons and increased the activity in the excised cotyledons. In the excised and seedling roots, the lack of phosphorus, its deficiency and stress imposed by the addition of $\mathrm{NaCl}$, caused an increase in total and specific phosphatase activity. Osmotic stress caused proline accumulation in both the seedling and excised cotyledons, but the effect of phosphorus stress was much smaller. Proline increase in seedling roots followed only after the osmotic stress caused by $\mathrm{NaCl}$. The proline content in the excised roots was low. Stress factors lowered the protein content in the seedling and excised cotyledons. In both seedling and excised roots, the lowering of the protein content occurred mainly in response to osmotic stress. Kinetin modified metabolic responses in seedling cotyledons and roots. The use of in vitro culture allowed the elucidation of the tested responses. In excised cotyledons grown under stress conditions, kinetin increased the phosphorus and protein contents and lowered proline accumulation, suggesting that kinetin had the ability to overcome phosphorus and osmotic stress. The excised oilseed rape roots responded only slightly to kinetin (Drozdowska and Rogozińska 1984) and its effect was much smaller.
\end{abstract}

Key words: water and phosphorus stress, phosphatase activity, proline accumulation

\section{INTRODUCTION}

Phosphorus deficit in the environment evokes a series of modifications in the metabolism of plants. One of them is an increase in the activity 
of acid phosphatase (Bieleski 1973, Barrett-Lennard et al. 1982, Dracup et al. 1984). Significant changes also take place in the metabolism of nitrogen compounds. Indications of these changes are, among others, partial inhibition of protein synthesis and the accumulation of free amino acids such as proline, arginine and glutamic acid (Ranjan and Malaviya 1962, Savickaya 1976, Rabe and Lovatt 1984). The accumulation of free amino acids, especially proline, is also a characteristic response of plants to osmotic stress (Singh et al. 1973, Hsiao 1973, Aspinall and Paleg 1981, Hanson and Hitz 1982).

It has been suggested that the metabolic modifications caused by water or phosphorus stress can be related to, among others, quantitative changes in endogenous growth regulators. The effect of stresses on lowering the cytokinin content in plants has been demonstrated by many authors (Hsiao 1973, Dhillon 1978, Salama and Wareing 1979, Darrall and Wareing 1981, Radin 1984). The consequences of stress can be allayed with exogenous growth regulators (Hsiao 1973, Milborrow 1981).

This paper presents a continuation of studies on the influence of stress factors on some of the metabolic responses of winter rape (Rogozińska and Flasiński 1983, Flasiński and Rogozińska 1985 - in press). The objective was to determine the influence of phosphorus and osmotic stress on phosphatase activity and proline accumulation in seedling cotyledons and roots in comparison with in vitro cultures of these organs. Kinetin was also used in order to reveal its effect on the metabolic changes accompanying stresses.

\section{MATERIAL AND METHODS}

Seedling cultures. Rape seeds (Brassica napus L. var. oleifera cv. Skrzeszowicki) were surface sterilized with $0.2 \%$ mercuric chloride, after which they were rinsed with sterile water and placed on $0.8 \%$ agar, where they germinated. Three day-old seedlings were transferred to water cultures on diluted $(2 \times)$ Hoagland's medium. The seedlings were placed in a phytotron (prototype: OBRUCiG, Bydgoszcz) at $12000 \mathrm{~lx}$ light intensity (type LRJb $400 \mathrm{~W}$ mercury-vapor lamps) and a $12 \mathrm{hr}$ photoperiod, a temperature of $24 \pm 2 \mathrm{C}$ and $70 \%$ humidity. After 7 days of growth, the seedlings were transferred to media containing different levels of phosphorus: 0,10 . 500 and $3500 \mu \mathrm{M}$ (control $500 \mu \mathrm{M}$ ). Osmotic stress was evoked by using polyethylene glycol (PEG) $6000\left(198 \mathrm{~g} \cdot \mathrm{dm}^{-3}\right)$ or sodium chloride $(\mathrm{NaCl}$ $11.69 \mathrm{~g} \cdot \mathrm{dm}^{-3}$ ), according to the method given by Tal et al. (1979). The osmotics were added in portions (PEG after 7 and 12 days, $\mathrm{NaCl}$ after 7 and 9 days) which resulted in lowering the water potential to about $-1 \mathrm{MPa}$. The kinetin treated seedlings were sprayed with a solution $\left(10 \mathrm{mg} \cdot \mathrm{dm}^{-3}\right.$ kinetin) containing Tween 40 three days prior analysis. 
In vitro cultures. Cotyledons and $1 \mathrm{~cm}$ long apical root segments were excised from three day-old, sterile seedlings and transferred to a liquid Murashige and Skoog medium (cotyledons) or to a Bonner-Devirian medium (roots). Media with growth-stimulating concentrations of kinetin were used for cultivation of cotyledons and roots: cotyledons $+10 \mu \mathrm{M}$ (Rogozińska and Drozdowska 1980), roots $+0.005 \mu \mathrm{M}$ (Drozdowska and Rogozińska 1984). After 7 days of culture, the cotyledons and roots were transferred to media with different levels of phosphorus in order to evoke phosphorus stress. Medium containing no phosphorus, $50 \times$ less or $7 \times$ more phosphorus than in the control medium were used, analogously as in seedling cultures. The basic Murashige and Skoog $(1250 \mu \mathrm{M} \mathrm{P})$ or Bonner-Devirian $(150 \mu \mathrm{M})$ media were used as controls. Osmotic stress was evoked analogously as in seedling cultures, by adding $\mathrm{NaCl}$ or PEG to the media. The latter was added in portions on the 7 th and 12th days of culture, in order to ensure the survival of the cotyledons and roots and their adaptation to stress conditions.

The cotyledon and root cultures were placed in a culture room at a temperature of $25 \pm 2^{\circ} \mathrm{C}$, in a laboratory shaker (type 358S) set at 60 cycles per minute for a period of $12 \mathrm{hrs}$ per day. A $12 \mathrm{hr}$ photoperiod with approx. $1500 \mathrm{~lx}$ was used.

The biochemical analyses of the seedling cotyledons and roots from water and in vitro cultures were done after 7, 10, 14 and 21 days of growth, which is equivalent to $0,3,7$ and 14 days of stress. Phosphorus was determined by the Fiske-Subbarow method (1925) following digestion of dried plant samples in $2.5 \mathrm{M} \mathrm{H}_{2} \mathrm{SO}_{4}$ and $70 \% \mathrm{HClO}_{4}$ (5:1). The activity of acid phosphatase was determined by the Walter and Shütt method (1974) using p-nitrophenyl phosphate as the substrate. The enzyme unit (U) was taken to be the amount of enzyme which produces $1 \mu \mathrm{M}$ p-nitrophenol in 1 minute at $30^{\circ} \mathrm{C}$. Proline was determined after Bates et al. (1973). Protein was isolated with $50 \mathrm{mM}$ Tris- $\mathrm{HCl}$ buffer, $\mathrm{pH} 7.5$, containing $1 \mathrm{mM}$ EDTA and $0.5 \mathrm{M} \mathrm{NaCl}$, after which the homogenate was centrifuged for $12 \mathrm{~min}$ at $20000 \times \mathrm{g}$ at $+4^{\circ} \mathrm{C}$. Protein was determined using the method of Lowry et al. (1951) with bovine serum albumin as the standard. The presented results are the means of three replicates.

\section{RESULTS}

SEEDLING COTYLEDONS AND ROOTS

Water or phosphorus deficits in the medium inhibited seedling growth, which could already be observed after 1 week of culture under stress conditions (Fig. 1A, B). Characteristic stress symptoms, such as darker leaf 
color and anthocyanin blemishes in the case of phosphorus, also appeared. Stress evoked by PEG caused marginal chlorosis of leaves and their drying up while salt stress caused chlorosis of the entire leaf blades. The use of kinetin only slightly increased the growth of plants and the symptoms evoked by stress agents were somewhat alleviated (Fig. 1C).

The symptoms were accompanied by certain metabolic modifications. The studies on the effect of phosphorus stress showed that initially, the phosphorus content in control cotyledons increased, and then fell during growth of the seedlings. The lack, deficit or excess of phosphorus in the medium, accelerated the lowering of the phosphorus content. Spraying the seedlings with kinetin delayed somewhat the withdrawal of phosphorus from the cotyledons. Under the conditions of water and salt stress, the phosphorus content in the cotyledons was similar as in the cotyledons of control plants (Fig. 2A).

The total activity of plant cotyledon acid phosphatase was rather variable at different phosphorus levels. Stress factors such as PEG or $\mathrm{NaCl}$ caused an increase in its activity (Fig. 2B). The specific activity of acid phosphatase in cotyledons was also dependent on the phosphorus level and water potential of the medium. The highest increase in the specific activity in the cotyledons was found after 3 days of phosphorus stress or 7 days of osmotic stress (Fig. 2C).

Proline accumulation was not found in the cotyledons of seedlings growing under phosphorus stress. It was, however, significant under conditions of osmotic stress, especially that caused by PEG. The curves showing the accumulation of proline in cotyledons of seedlings treated with kinetin were similar (Fig. 2D).

The protein content in cotyledons of plants grown on the control medium initially increased, then was maintained on a rather constant level. Phosphorus and osmotic stresses caused a fall in the protein content and kinetin had only a slight influence on it (Fig. 2E).

The roots also showed specific reactions to the stress factors used. The amount of phosphorus in the roots was clearly dependent on its level in the medium. Under conditions of lack of phosphorus or its deficit, a minimal increase in its content occurred, whereas it was significantly higher in the roots of control seedlings. Under conditions of phosphorus excess, its content expressed per seedling root, was the highest, attaining twice the control level on the 14th day of stress. No effect of spraying the seedlings with a solution of kinetin on the root phosphorus content was found. The water deficit caused by PEG or $\mathrm{NaCl}$ did not lower the phosphorus content of the roots (Fig. 2A').

The amount of phosphorus in the medium also had an effect on the changes in the activity of acid phosphatase. A rise in the total phosphatase 

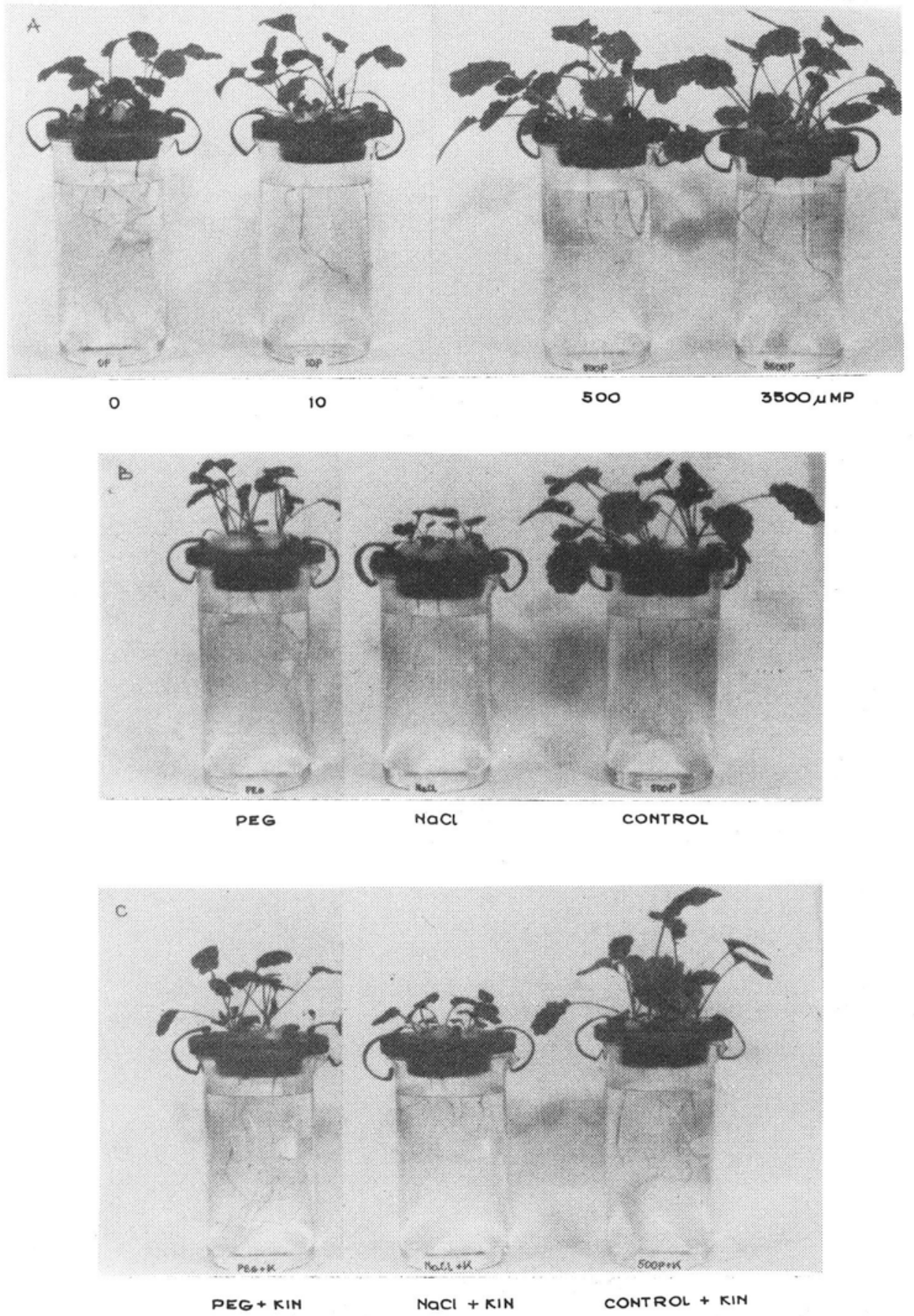

Fig. 1. Growth of oilseed rape seedlings in water culture depending on stress conditions: A - the effect of phosphorus stress; B - the effect of osmotic stress (-1 MPa); C - the effect of osmotic stress $(-1 \mathrm{MPa})$ and kinetin $\left(10 \mathrm{mg} \cdot \mathrm{dm}^{-3}\right)$ 

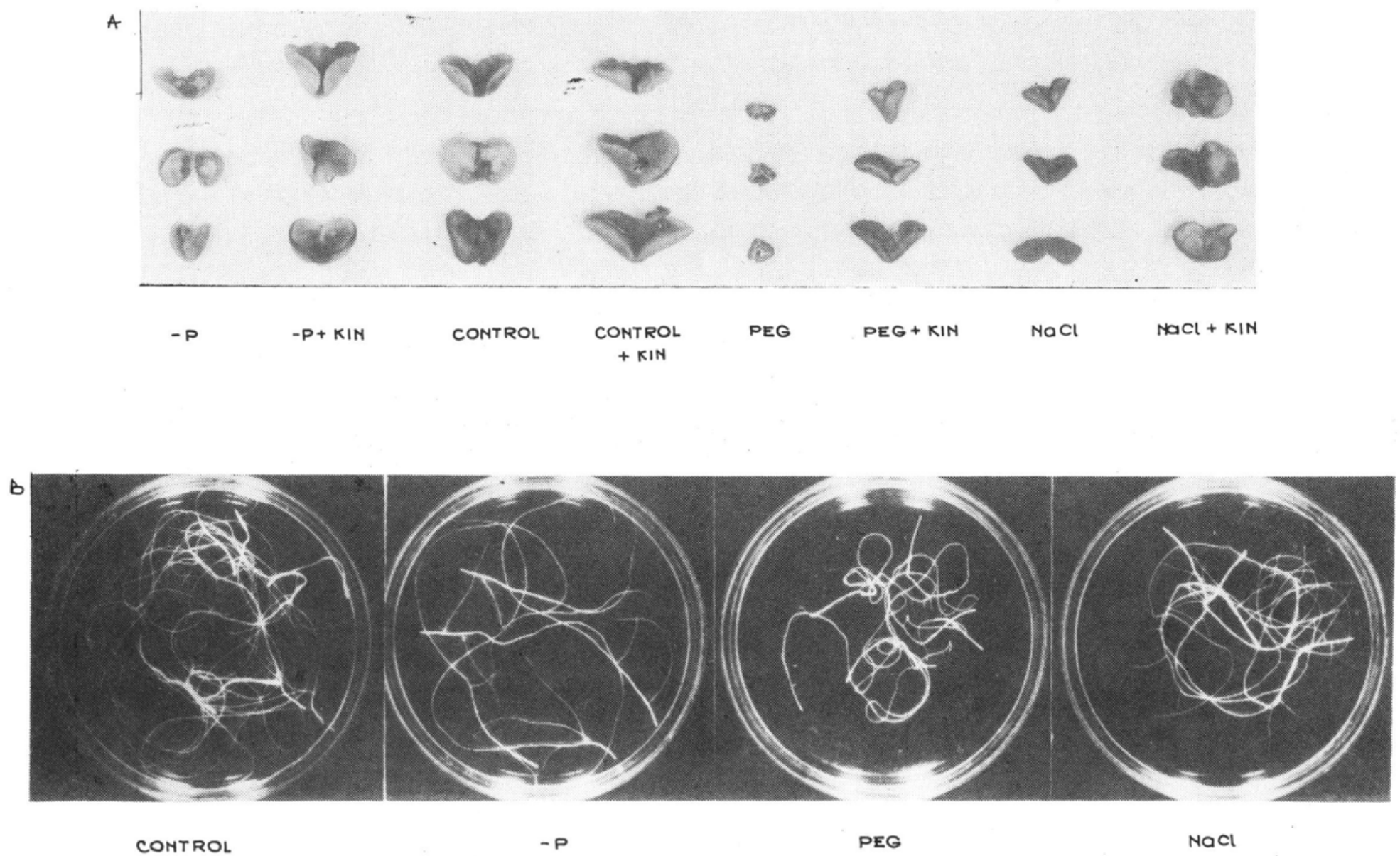

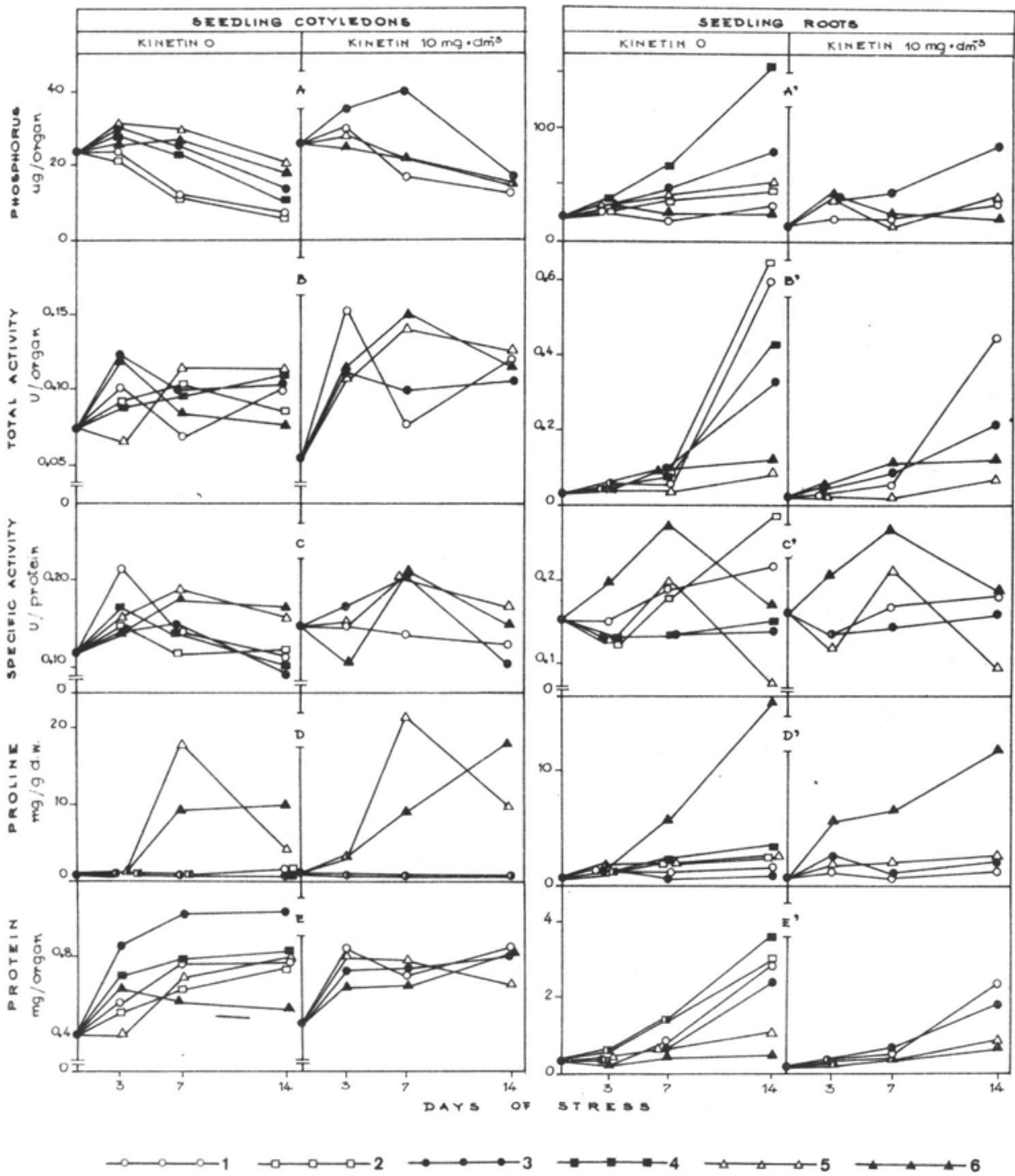

Fig. 2. The effect of phosphorus and osmotic stress $(-1 \mathrm{MPa})$ on seedling cotyledons (A-E) and roots $\left(\mathrm{A}^{\prime}-\mathrm{E}^{\prime}\right)$ : A - phosphorus content; B - total phosphatase activity; C - specific phosphatase activity; D - proline accumulation; E - protein content (1 - lack of phosphorus; 2 -P deficiency, $10 \mu \mathrm{M} ; 3$ - control, $500 \mu \mathrm{M}$ P; 4 - $\mathrm{P}$ excess, $3500 \mu \mathrm{M} ; 5-\mathrm{NaCl}$; 6 - PEG)

Fig. 3. The effect of phosphorus and osmotic stress $(-1 \mathrm{MPa})$ on the growth of excised cotyledons (A) and roots (B) of oilseed rape 
activity in seedling roots began on the 3rd day of stress under lack or deficit of phosphorus in the medium. The activity of phosphatase was also slightly higher than in the roots of control seedlings when there was an excess of phosphorus. Kinetin caused the lowering of phosphatase activity in roots of seedlings growing on the control medium as well as those growing on the medium without phosphorus. The total activity of phosphatase in the roots of seedlings growing on media with PEG or $\mathrm{NaCl}$ was maintained on a rather constant level, which is related to the inhibition of their growth. An increase in activity in response to kinetin was found only in roots growing under conditions of salt stress (Fig. $\left.2 \mathrm{~B}^{\prime}\right)$. The specific activity of phosphatase in roots growing under phosphorus stress rose with the increase of stress duration. Water deficit caused a significant increase in specific activity only to the 7 th day of stress. This activity was lower in the roots of seedlings treated with kinetin and growing on the medium without phosphorus. However, no effect of kinetin was found on the specific activity of phosphatase in the roots of seedlings growing under conditions of osmotic stress (Fig. 2C').

The modifications of the root phosphorus metabolism were accompanied, similarly as in the cotyledons, by changes in the nitrogen compund content. The proline content in roots subjected to phosphorus and water stress was slightly higher than in the control. Only salt stress influenced proline accumulation, with kinetin bringing about its decrease (Fig. 2D').

The root protein content increased gradually during the development of the seedlings. Phosphorus stress caused a slight increase in this content. The protein content under osmotic stress conditions was, however, significantly lower than in the roots of seedlings growing on the control medium (Fig. 2E').

Thus, these results show that the studied metabolic responses such as acid phosphatase activity, proline accumulation and protein content, depended on the type of stress, its duration and organ. The most characteristic reaction of rape seedling cotyledons subjected to osmotic stress was the accumulation of proline. However, in roots growing under phosphorus stress, the characteristic modification was an increase in the activity of acid phosphatase. The results presented here suggest that kinetin may change the responses of rape to phosphorus and osmotic stress. When kinetin was used to spray whole plants, its action was not continuous. In order to obtain fuller information on the effect of kinetion on the stress responses under study, experiments using in vitro cultures were done.

The use of excised cotyledons and roots in culture allowed the influence of kinetin on the evoked stress responses to be determined more precisely. 
After a few days of incubation of the cotyledons on the control medium, they were found to enlarge and turn green. Kinetin greatly enhanced this effect. The stress factors employed (lack of, lowered or increased phosphorus level. addition of PEG or $\mathrm{NaCl}$ to the culture medium), inhibited cotyledon growth to various extents. Water stress evoked by PEG also caused. in addition to growth inhibition. their yellowing. The stress factors applied in the presence of kinetin did not cause growth inhibition to such a great extent (Fig. 3A).

These symptoms were preceded by metabolic modifications. In the studies on the effect of phosphorus. a precise correlation between the amount of phosphorus in the medium and in the cotyledons was demonstrated. Initially, a significant increase in the amount of phosphorus was found in the cotyledons growing on the control medium the amount of this element was then maintained on a rather constant level.

The phosphorus content in the cotyledons was higher under the influence of kinetin. The stress factors caused the lowering of the phosphorus content in the following order: $\mathrm{NaCl}$. PEG lack of phosphorus. In the presence of kinetin. the stress factors caused the lowering of the cotyledon phosphorus content similarly as on the medium without kinetin (Fig. 4A). The phosphorus content in cotyledons was about 5 times higher at the end of the stress period when the medium contained an increased level of phosphorus.

The phosphorus metabolism of excised cotyledons had, therefore. undergone changes, which are indicated by the total and specific activities of the studied phosphatase. When the medium lacked phosphorus, the total activity in the cotyledons was somewhat higher. Osmotic stress caused a certain lowering of the activity in the final period of cotyledon growth. Kinetin caused differentiation of the total activity of phosphatase depending on the studied stress factors (Fig. 4B). The specific activity of phosphatase was gradually lowered as the protein content of the cotyledons increased on successive days of culture, whereas the stress factors did not cause differentiation of specific activity. The specific activity in cotyledons also fell in the presence of kinetin, although in the initial stage of stress only. under conditions of lack of phosphorus. this activity was slightly increased (Fig. 4(').

Another characteristic response to the stress factors used was the accumulation of proline. The proline content in the cotyledons grown on the control medium and under phosphorus stress, was insignificant. However, under osmotic stress, proline accumulation was very intense and amounted to about 4 times that of control cotyledons. Kinetin caused the accumulation of proline brought about by osmotic stress to be lowered (Fig. 4D).

The cotyledon protein content was correlated with their different growth 

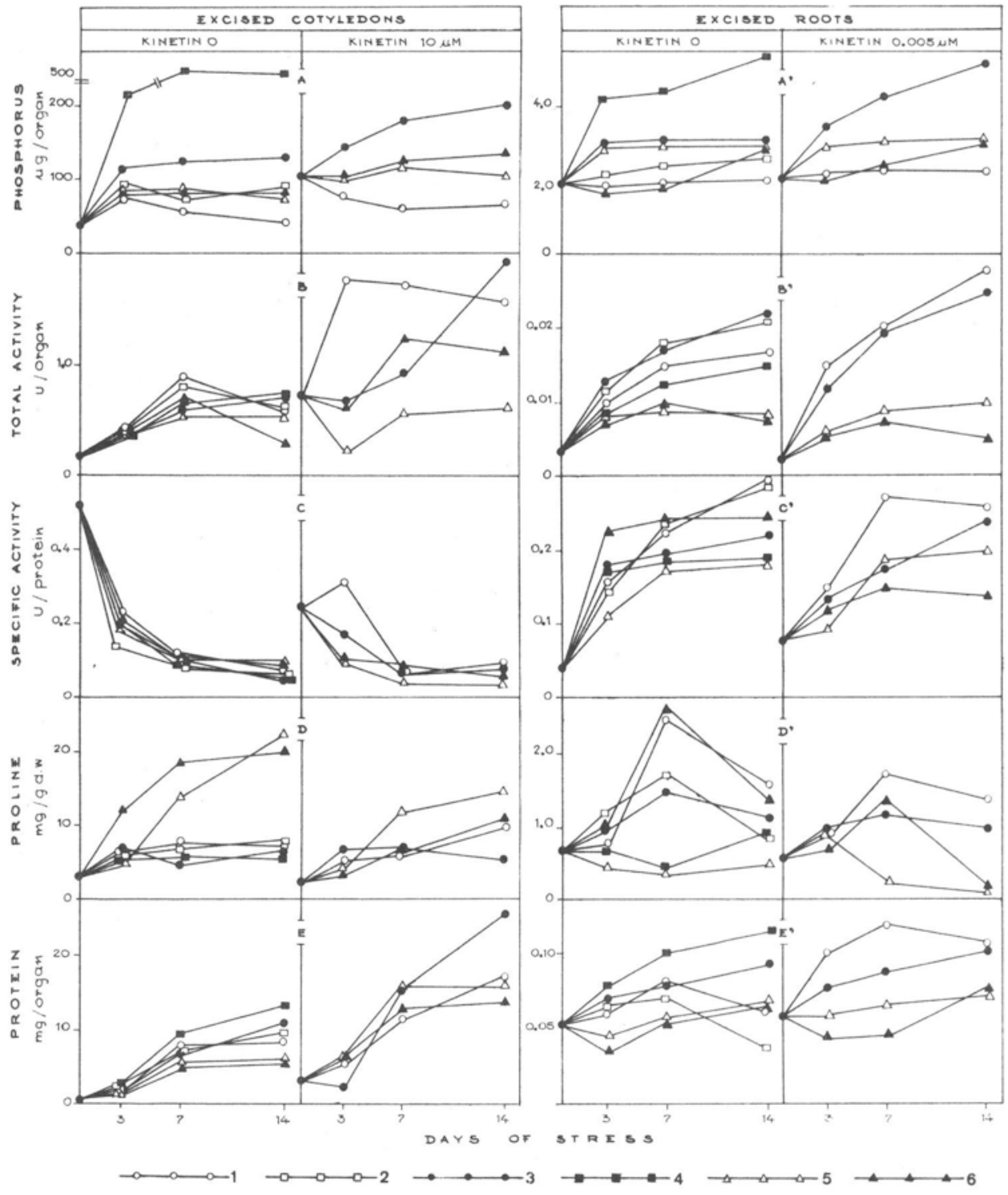

Fig. 4. The effect of phosphorus and osmotic stress $(-1 \mathrm{MPa})$ on excised cotyledons (A-E) and roots $\left(\mathrm{A}^{\prime}-\mathrm{E}^{\prime}\right) ; \mathrm{A}$ - phosphorus content: $\mathrm{B}$ total phosphatase activity: C specific phosphatase activity: D - proline accumulation: $E$ protein content ( 1 lack of phosphorus: $2-\mathrm{P}$ deficiency. cotyledons $125 \mu \mathrm{M}$, roots $15 \mu \mathrm{M}: 3$ control, cotyledons $1250 \mu \mathrm{M} \mathrm{P}$, roots $150 \mu \mathrm{M} \mathrm{P}: 4-\mathrm{P}$ excess, cotyledons $8500 \mu \mathrm{M}$, roots $1050 \mu \mathrm{M} ; 5$ $\mathrm{NaCl} ; 6$ - PEG) 
on the individual medium variants. On the control medium, this content increased on successive days of growth. Whereas in cotyledons grown on media with stress factors, after an initial increase, the amount of protein was maintained on a rather constant level; kinetin caused an increase in this content (Fig. 4E).

The growth of the roots was also dependent on the stress factors used. The highest inhibition of growth took place under the influence of the stress evoked by $\mathrm{PEG}$, next by $\mathrm{NaCl}$ and the exclusion of phosphorus from the medium (Fig. 3B). As in the cotyledons, the responses accompanying phosphorus and water stress, such as proline accumulation, protein content and phosphatase activity, were also studied.

In the roots grown on the control medium, an increase in the phosphorus level was found in the initial period of culture, whereas in the presence of kinetin, it rose during the entire period. The stress factors used caused the phosphorus content to fall, regardless if kinetin was applied or not. Of course, when the phosphorus content in the medium was increased, its content in the roots was also higher (Fig. 4A').

The total activity of acid phosphatase in roots cultivated on the control medium increased during the successive days of culture. The stress factors used caused a lowering of this activity. A clear effect of kinetin was found only when phosphorus was lacking in the medium (Fig. 4B'). Also, the specific activity of phosphatase in roots cultivated on the control medium, and, especially, on the medium lacking phosphorus, was increased. Under water stress conditions, the activity increased up until the 7th day of stress. Kinetin caused the lowering of the specific activity only in roots growing in the medium with $\mathrm{NaCl}$ (Fig. 4C').

As in the case of seedling roots, the proline content in roots cultured in vitro, was insignificant. From among the studied stress factors, only the addition of $\mathrm{NaCl}$ to the medium or the exclusion of phosphorus slightly increased its content (Fig. 4D').

The protein content in the roots grown on the control medium was higher than in roots grown under stress. Kinetin caused a rise in this content only in roots grown under conditions of lack of phosphorus (Fig. 4E').

\section{DISCUSSION}

Water and phosphorus deficits in the environment cause metabolic modifications and a significant limitation of plant growth. The effect of these stress factors is specific (Bieleski 1973. Hanson and Hitz 1982), although certain metabolic responses evoked by phosphorus and water deficits 
are similar. This would suggest that different stress factors cause in plants the mobilization of similar protective mechanisms.

Quantitative changes in endogenous growth regulators take place during water deficit. Among others, a rise in the abscisic acid content and a drop in the cytokinin and gibberellin contents have been demonstrated (A haroni et al. 1977. Milborrow 1981). A low phosphorus level may also influence the fall in the cytokinin content (Salama and Wareing 1979). This is caused by the lowering of the water conduction of roots and increasing the stomata diffusion resistance in addition to the inhibition of cytokinin synthesis in plants (Radin 1984).

The experiments presented in this paper have shown that kinetin allayed the inhibitory effect of water salt and phosphorus stress on the growth of rape cotyledons. Among the many physiological effects of cytokinins on plants, their effect on opening of stomata should be mentioned ( $\mathrm{Hsiao}$ 1973). As is suggested by Milborrow (1981), the opening of stomata induced by kinetin is caused by the reduction of osmotic potential which results in an increased water uptake. For this reason kinetin could facilitate gas exchange and absorbance of nutrients and accelerate rape cotyledon growth, especially when cultured in vitro.

Under conditions of phosphorus deficit, the content of this element in plants drops (Bieleski 1973. Barrett-Lennard et al. 1982, Dracup et al. 1984), which has been confirmed by these studies on oilseed rape. It is also known that osmotic shock inhibits the absorption of phosphates by roots (Migliaccio et al. 1984). although this is not always accompanied by a fall in the phosphorus content of the plant. e.g. in the case of serious inhibition of its growth. As has been shown in this study, the phosphorus content in the cotyledons of plants subjected to water stress was somewhat higher than in the cotyledons of control plants. The application of stress caused the differentiation of the physiological state of control and stressed plants. Phosphorus is a very mobile element, and as seedlings grow, it is withdrawn from the cotyledons to leaves. However, the process of phosphorus withdrawal was delayed in plants subjected to water stress. due to the serious inhibition of their growth.

It was demonstrated that the control rape plants sprayed with kinetin had a somewhat higher phosphorus content in their cotyledons than did the plants not treated with kinetin. It is known that cytokinins activate plant metabolism. In the early stages of seedling growth. kinetin plays a role, among others in the acceleration of the transformation of cotyledons from storage into photosynthesizing organs (Fantelli et al. 1984). Then, during leaf development, it can stimulate the withdrawal of various metabolites from aging cotyledons. The excised rape cotyledons also responded in a specific manner to the stress factors used. Under stress conditions, the phosphorus 
level was lowered and kinetin accelerated its uptake. In the roots of seedlings, due to the inhibition of phosphorus absorption under conditions of osmotic stress or lack of phosphorus, the phosphorus content was lower than that in the control roots.

The activity of acid phosphatase, an enzyme regulatıng the phosphorus metabolism in plants. undergoes changes under stress conditions. An increase in the activity of this enzyme under water and phosphorus stress has been demonstrated by Bieleski (1973), Aspinall and Paleg (1981) and Barrett-Lennard et al. (1982). These studies on oilseed rape showed a very high increase in phosphatase activity, especially in seedling and excised roots subjected to phosphorus stress. Kinetin prevented excessive rise in phosphatase activity while it stimulated this growth in control seedling roots. Because the plants treated with kinetin tolerated the phosphorus deficit somewhat better. it should be supposed that the excessive increase in the hydrolytic activity of phosphatase induced by phosphorus stress is unfavorable for plants.

As given by Ferens and Morawiecka (1984), the activity of acid phosphatase in physiological processes is under the clear control of a multi-staged, hormonal regulation system. Changes in phosphatase activity also are an expression of the organism's responses to changes in its environment. For example. when there is a phosphate deficit, phosphatase activity is regulated through de novo synthesis of the enzyme and by freeing it on the exterior of the cell (Bieleski 1973. Barrett-Lennard et al. 1982). Stress therefore very quickly modifies plant metabolism, among others, by bringing about disorders in the ion balance and accumulation of various metabolites. Many metabolites, especially proline, which under normal conditions is incorporated into proteins or oxydated. is accumulated as the result of stress (Aspinall and Paleg 1981). The greatest accumulation of proline was found in the cotyledons of rape plants and excised cotyledons subjected to osmotic stress. As was shown before the accumulation of proline in rape is very intense, especially in leaves and generative organs (Rogozińska and Flasiński 1983. Flasiński and Rogozińska 1985 - in press). Growth regulators may play a certain role in the accumulation of proline during stress (Hsiao 1973. Aspinall and Paleg 1981). Cytokinins the amount of which lessens during stress (water, salt and phosphorus stress) inhibited the synthesis of proline in isolated barley and radish leaves (Aspinall and Paleg 1981). Also, in excised rape cotyledons subiected to water or salt stress, a lower proline content was found in the presence of kinetin. However, the effect of kinetin on the proline accumulation in the cotyledons of intact rape plants growing under stress was only slight, similarly as was found in the leaves of other species of plants (Palfi 1968, Balasimha 1983). 
The growth of plants is dependent. among other things, on protein biosynthesis: stress factors inhibit this biosynthesis and accelerate degradation (Hsiao 1973, Aspinall and Paleg 1981, Hanson and Hitz 1982. Rogozińska and Flasiński 1983). It was demonstrated that the protein level of seedling cotyledons dropped due to both osmotic and phosphorus stress, and in roots, only under osmotic stress. Phosphorus stress caused an increase in the root protein content, which may be related to the higher rhizogenic activity under conditions of mineral deficiency. In analogical studies run on excised cotyledons and roots in in vitro cultures, the effect of stress factors was shown more precisely, especially in the presence of kinetin. A sharp fall in the protein content was found, which was smaller in the presence of kinetin. Support for the key role of cytokinins in modulating protein synthesis comes from their ability to partially reverse the stress-caused inhibition of incorporation of ${ }^{14} \mathrm{C}$-leucine into protein. Kinetin may also influence the protein level by inhibiting proteolysis (Hsiao 1973, Milborrow 1981).

The effect of kinetin on oilseed rape plants growing under stress was various, which is indicated by the assays of proline content and phosphatase activities in cotyledons and roots. In the studies done on excised cotyledons and roots treated continuously with kinetin, the attenuating effect of kinetin on the characteristic stress reactions was evident. Kinetin may therefore act by activating those metabolic processes which increase the chance of survival of plants in unfavorable environmental conditions.

\section{REFERENCES}

Aharoni N., Blumenfeld A., Richmond A. E., 1977. Hormonal activity in detached lettuce leaves as affected by leaf water content. Plant Physiol. 59: 1169-1173.

Aspinall D., Paleg L. G., 1981. Proline accumulation: physiological aspects. In: The physiology and biochemistry of drought resistance in plants. Paleg L.. Aspinall D. (eds.). Academic Press, Sydney-New York-London. pp. 205-241.

Balasimha D.. 1983. Effect of abscisic acid and kinetin on growth and proline accumulation in cacao seedlings under water stress. Indian J. Plant Physiol. 26: 139-142.

Barrett-Lennard E. G., Robson A. D., Greenway H., 1982. Effect of phosphorus deficiency and water deficit on phosphatase activities from wheat leaves. J. Exp. Bot. 33: 682-693.

Bates L. S., Waldren R. P., Teare I. D., 1973. Rapid determination of free proline for water-stress studies. Plant and Soil 39: 205-207.

Bieleski R. L., 1973. Phosphate pools, phosphate transport and phosphate availability. Ann. Rev. Plant Physiol. 24: 225-252.

Darrall N. M., Wareing P. F.. 1981. The effect of nitrogen nutrition on cytokinin activity and free amino acids in Betula pendula Roth. and Acer pseudoplatanus L. J. Exp. Bot. 32: 369-379 
Dhillon S.S., 1978. Influence of varied phosphorus supply on growth and xylem sap cytokinin level of sycamore (Platanus occidentalis L.) seedlings. Plant Physiol. 61: 521-524.

Dracup M. N. H.. Barrett-Lennard E. G.. Greenway H.. Robson A. D.. 1984. Effect of phosphorus deficiency on phosphatase activity of cell walls from roots of subterranean clover. J. Exp. Bot. 35: 466-480.

Drozdowska L., Rogozińska J., 1984. Effect of growth regulators and light conditions on the morphogenesis of excised oilseed rape roots. Biul. PAN 32: 429-433.

Fantelli R., Longo G. P., Rossi G., Longo C. P., Vitelli B., 1984. Interaction between benzyladenine and fusicoccin on the development of excised watermelon cotyledons.

I. Growth and organelle development. Plant Sci. Lett. 33: 269-275.

Ferens M., Morawiecka B., 1984. Kwaśne fosfatazy roślin wyższych. Post. Bioch. 30: 461-475.

Fiske C. H., Subbarow Y., 1925. The colorimetric determination of phosphorus. J. Biol. Chem. 66: 375-400.

Flasiński S., Rogozińska J., 1985. Effect of water deficit on proline accumulation, protein and chlorophyll content during flowering and seed formation in winter rape (Brassica napus L. var. oleifera). Acta Agrobot. (in press).

Hanson A. D., Hitz W. D., 1982. Metabolic responses of mesophytes to plant water deficits. Ann. Rev. Plant Physiol. 33: 163-203.

Hsiao T.C.. 1973. Plant responses to water stress. Ann. Rev. Plant Physiol. 24: 519-570.

Lowry O. H., Rosebrough N. J., Farr A. L., Randall R. J., 1951. Protein measurement with the Folin phenol reagent. J. Biol. Chem. 193: 265-275.

Migliaccio F., Mass E. V., Ogata G., 1984. Phosphate absorption, fluxes and symplasmic transport in osmotically-shocked Zea mays roots. J. Exp. Bot. 35: 8-17.

Milborrow B. V., 1981. Abscisic acid and other hormones. In: The physiology and biochemistry of drought resistance in plants. Paleg L. G.. Aspinall D. (eds.). Academic Press, Sydney-New York-London. pp. 348-388.

Palfi G., 1968. Die Wirkung von Kinetin. 2,4-DNP und Antimetaboliten auf die Veränderungen im Aminosäurengehalt welkender Pflanzenblätter. Planta 78: 196-199.

Rabe E.. Lovatt C. J.. 1984. De novo arginine biosynthesis in leaves of phosphorus-deficient (itrus and Poncirus species. Plant Physiol. 76: 747-752.

Radin J.W., 1984. Stomatal esponses to water stress and to abscisic acid in phosphorus-deficient cotton plants. Plant Physiol. 76: 392-394.

Ranjan S.. Malaviya B.. 1962. Effect of phosphorus deficiency on the free and protein bound amino acids of the linseed plant. Flora 152: 399-408.

Rogozińska J.. Drozdowska L., 1980. Organogenesis and plant formation from cotyledon and callus cultures of rape. Acta Soc. Bot. Pol. 49: 5-20.

Rogozińska J., Flasiński S., 1983. Wpływ stresu somotycznego na akumulacię proliny u rzepaku. Zeszyty Naukowe ATR, 108. Rolnictwo 16: 5-9.

Salama A. M. S., Wareing P. F., 1979. Effects of mineral nutrition on endogenous cytokinins in plants of sunflower (Helianthus annuus L.). J. Exp. Bot. 30: 971-981.

Savickaya N. N.. 1976. O fizjologicheskoi roli prolina w rastieniakh Nauch. Dokl. Wyzhsh. Shkoly. Biol. Nauki. 2: 49-61.

Singh T. N., Paleg L. G.. Aspinall D.. 1973. Stress metabolism. I. Nitrogen metabolism and growth in the barley plant during water stress. 26: 45-56.

Tal M.. Katz A.. Heikin H.. Dehan K.. 1979. Salt tolerance in the wild relatives of the cultivated tomato: proline accumulation in Lycopersicon esculentum Mill., L. peruviamum Mill. and Solanum pennelli Cor. treated with $\mathrm{NaCl}$ and polyethylene glycol. New Phytol. 82: 349-355. 
Walter K., Schütt C.. 1974. Acid and alkaline phosphatase in serum. In: Methods of enzymatic analysis. Bergmeyer H. U. (ed.). Academic Press. New York-San Francisco-London. pp. 856-860.

Wplyw fosforu i deficytu wody na aktywność fosfatazy i akumulację proliny $w$ liścieniach $i$ korzeniach siewek rzepaku $w$ kulturach wodnych $i w$ kulturach in vitro

\section{Streszczenie}

Siewki rzepaku i izolowane liścienie i korzenie były eksponowane na stres fosforowy i osmotyczny (-1 MPa: $\mathrm{NaCl}$ lub PEG). Czynniki stresowe graniczały wzrost siewek $i$ hamowały wzrost izolowanych liścieni $\mathrm{i}$ korzeni. Zawartość fosforu w liścieniach i korzeniach była zależna od iego poziomu w pożywce i czynników stresowych. Niedobór fosforu powodował pewne zróżnicowanie aktywności ogólneł fosfatazy w liścieniach siewek a w liścieniach izolowanych aktywność ta ulegała podwyższeniu. W korzeniach siewek i korzeniach izolowanych brak i niedobór fosforu oraz stres wywołany przez $\mathrm{NaCl}$ wplywały na zwiększenie aktywności ogólnei i właściwei fosfatazy. Stres osmotyczny powodował akumulacię proliny w liścieniach siewek $\mathrm{i}$ w liścieniach izolowanych. natomiast wplyw stresu fosforowego był nieznaczny. Podwyższenie poziomu proliny w korzeniach siewek następowało tylko pod wpływem stresu osmotycznego wywolanego przez $\mathrm{NaCl}$. W korzeniach izolowanych zawartość proliny była nieznaczna. Czynniki stresowe wpływały na obniżenie zawartości białka w liścieniach siewek i w liścieniach izolowanych. W korzeniach siewek i korzeniach izolowanych obniżenie zawartości białka nastąpiło glównie pod wpływem stresu osmotycznego. Kinetyna modyfikowała reakcie metaboliczne $\mathrm{w}$ liścieniach $\mathrm{i}$ korzeniach siewek. Zastosowanie kultur in vitro pozwoliło na wyjaśnienie badanych efektów. W izolowanych liścieniach hodowanych w warunkach stresowych kinetyna wpływała na zwiększenie zawartości fosforu i białka oraz obniżała akumulacię proliny co sugeruje. że kinetyna może przezwyciężyć stres osmotyczny i fosforowy. Izolowane korzenie rzepaku nie reaguia zbyt silnie na kinetyne (Drozdowska i Rogozińska. 1984) w związku z czym jej efekt na badane czynniki stresowe był mniejszy. 